\title{
Lessons from History: Human Anatomy, from the Origin to the Renaissance
}

\author{
Lecciones de Historia: Anatomía Humana, desde el Origen hasta el Renacimiento \\ ${ }^{*, * * *}$ A. O. Malomo; *O. E. Idowu \& *F. C. Osuagwu
}

MALOMO, A. O.; IDOWU, O. E. \& OSUAGWU, F. C. Leesons from history: Humana anatomy, from the origin to the renaissance. Int. J. Morphol., 24(1):99-104, 2006.

SUMMARY: The well-known fact that history writers always seem wiser than the subjects on whom they write is the most logical inherent proof that history is rich in lessons. The history of Anatomy is not an exception. It is full of imperative lessons in the Art and Science of the discipline of Anatomy, which following generations ought to learn. We present a defined brief survey with this in mind.

KEY WORDS: Hippocrates; Galen; Herophilus; Vesalius.

\section{INTRODUCTION}

The essential knowledge of anatomy has remained one of the basic principles of surgery over the centuries. Human anatomy is the 'physics' of medical sciences. The word anatomy was gotten from the Greek word "anatom?" meaning to cut up or to cut repeatedly ('ana'-up; 'tome'-cut) (Anson 1908).

The intellectual development of anatomy began in the golden age of Greece (Phillips 1973). The Greeks demonstrated unrelenting efforts to understand the workings of the living body and to build a coherent system of the workings. Hippocrates II was the first to write about human anatomy. The Greeks' pursuance was targeted at animal anatomy because dissection was forbidden on religious grounds then. This was largely out of respect for the dead and the then popular belief that dead human bodies still have some awareness of things that happen to it and therefore still had an absolute right to be buried intact and undisturbed.

After the fall of the Roman Empire, there was minimal progress in the development of anatomy. Its development was significantly slowed down by the doctrine, philosophy and practice of the authoritarian era. The advent of the renaissance about a 1000 years later witnessed a resurrection of its development.
The development of Neuroanatomy from the beginning to the renaissance has revolved around great men like Hippocrates, Aristotle, Herophilus, Galen and Vesalius.

Alcmaeon and Empedocles. The scientific dissection and vivisection of animals may have begun with the work of Alcmaeon (500 B.C.) of Crotona in Italy and Empedocles (490-430 B.C.) in Sicily. Alcmaeon was both a great physician and anatomist. He published a treatise entitled "On Nature"(Durant 1939b). In preparation for this book, he dissected many animals and described his findings in detail. This great anatomist was the first to describe and locate the optic nerve and the auditive tube (Eustachian tube), and he is also given the credit for proposing that the brain is the seat of consciousness, intelligence and emotions.

Empedocles, who believed that the heart distributed life-giving heat to the body, initiated the idea that an ethereal substance called pneuma, which was both life and soul, flowed through the blood vessels. Although such early anatomists were often incorrect, their work was essential to the development of later scientists.

Hippocrates II. Anatomical inferences without dissection continued in Greece with Hippocrates II (460-370

\footnotetext{
" Division of Neurological Surgery, Department of Surgery. University College Hospital and College of Medicine, University of Ibadan, Ibadan, Nigeria. "Department of Anatomy, University College Hospital and College of Medicine, University of Ibadan, Ibadan, Nigeria.
} 
B.C.), who is known as the Father of Medicine. Hippocrates of Cos was born to Heraclides and Phaenarete. His father and mother were descendants of Asclepius and Hercules respectively. He was a $17^{\text {th }}$-generation ancient Greek physician and the first to write about human anatomy even though he did not restrict himself in stricto sensu to anatomy. He might also be called the Father of Holistic Medicine, since he advocated the importance of the relationship between patient, physician, and disease in title diagnosis and treatment of illness. This philosophy was rejected at a time when diseases were still thought to be punishments from the gods. To him should go the credit for partially freeing medicine from mysticism and magic.

In spite of the mythical milieu in which he lived and practised with other physicians, Hippocratic books contained anatomical factual passages that were based on the inspection of skeletons as well as from observations of living bodies injured and uninjured. Seizing every opportunity to investigate his assumptions and develop his opinions he had some accurate observations on osteology. He demonstrated the sutures of the cranium, shape of the bones and their mutual connections. With respect to soft tissues, his ideas were largely erroneous. This error from inadequate observations and unconfirmed opinions is a pitfall from which we can all still learn today. In this respect, he relied on initial observations and formulation of ideas. We could say that in spite of his precocious empiricism, he was essentially an idealist. The concepts of hypothesis and experimentations for positive proofs were to come centuries later. He called the brain a gland, from which exudes a viscid fluid. He seems to be unaware of the central nervous system. He used the term nerve, to signify a sinew or a tendon. Many agrarian languages still use the same term for 'nerves' and 'tendons' today. Even then morphology, nomenclature and taxonomy were not concepts that occurred or were clear to any minds at that time. His believe was that the arteries were filled with air, an idea gained from their emptiness in dead animals (Durant 1939b), that the lungs consist of five ashcoloured lobes, the substance of which is cellular (honeycomb-like) and spongy, naturally dry, but refreshed by the air; and that the kidneys were glands, but possess an attractive faculty, by virtue of which the moisture of the drink is separated and descends into the bladder. Conceptually, and in arrears note worthy were his genius to move from descriptive work in to essential questions as well as his efforts to relate structure and form to function, in spite of the residual anthropomorphism in his paradigm. Anthropomorphism and personification were common in natural sciences in those days and are yet to completely vanish even today.

Aristotle. (384 - 322 B.C.), known as Aristoteles in most languages other than English, is one of the towering intellects of all times and considered by Charles Darwin as the world's greatest natural scientist. Along with Plato who was his teacher, he is often considered to be one of the two most influential and greatest natural philosophers in Western thought.

Maximising what was culturally available to him, Aristotle studied animals which he dissected and based his opinions of the human body on his findings in animals. He however merely speculated about the internal organs in humans based on the internal parts of animals most nearly allied to humans. Aristotle laid the foundation of comparative anatomy and established embryology on a scientific foundation by his direct studies of the chick embryo. His preformation theory of embryonic development survived in one form or the other until the $17^{\text {th }}$ century. The first three books of "Historia Animalium", a treatise consisting of ten books, and the four books on "The Parts of Animals", constitute the great monument of the Aristotelian Anatomy. In human anatomy Herophilus outclassed him, largely because Herophilus had human cadavers for study (Durant 1939a).

Aristotle was the first who corrected the erroneous statements of Polybus, Syennesis and Diogenes regarding the blood vessels, which they thought arose from the head and brain. He distinguished the thick, firm and more tendinous structure of the aorta from the thin and membranous structure of vein; he however mistook the ureters for branches of the aorta. Of the nerves he thought they arose from the heart and that they connect all articulated bones; in these, this great authority certainly made his conclusions more certain than his factual premises allowed. With the liver and spleen, and the whole alimentary canal, he was well acquainted.

A lot of credit however must go to this indisputable father of comparative anatomy. His venturing into embryology is contextually mind-boggling. The total effect of Aristotle on learning in arrears has been a mixed blessing. Prevailing idealism in philosophy and science kept the world merely speculating on his profound works, waiting for the renaissance to let in the fresh air and sunlight of empiricism.

Alexandrian Medical School. In the $3^{\text {rd }}$ century B.C., the modern idea of basing medicine on anatomy and physiology flourished in Alexandria, Egypt. The young Macedonian King later known as Alexander the Great founded Alexandria in 322B.C. The first two Ptolemies after the death of Alexander the Great devoted themselves to making Alexander the Literary and scientific centre of the Western world. The Alexandria Library was the largest and most complete library of antiquity. It was in the temple of Zeus and founded at the time that Greece was loosing some of its intellectual vigor (Gordon 1949). 
Ancient anatomy, except for the school of Alexandra in the time of Herophilus and Erasistratus, was largely animal anatomy.

Herophilus. From the region of Bosporus came Herophilus of Chalcedon, a pupil of Praxagoras (Edelstein 1967 and Gillespie 1980). Chalcedon is in present-day Turkey. Herophilus was a physician and an able surgeon and founded the science of Anatomy (he is often called the "father of anatomy"). He was thought to have lived between 325 and 255 B. C. (Von Staden 1989).

Herophilus was a true follower $\mathrm{f}$ Hippocratic thought. He broke only slightly from the doctrine of humors (the four biles: red bile, yellow bile, black bile and phlegm).

Courage, patience and painstakingness are necessary for good science: he engaged in the arduous task of developing anatomy register by determining anatomic nomenclature and forming the language of anatomy. The first documented human dissection was by him. This led to many anatomical discoveries through dissection of more than 600 cadavers of condemned criminals. Herophilus described the delicate arachnoid membranes, the cerebral ventricles, the venous sinuses especially the confluence of venous sinuses near the internal occipital protuberance (torcular Herophili), origin of nerves (he divided them into motor and sensory tracts) and differentiation of tendons from nerves (which were confusing at that time), the lacteals, coverings of the eye, liver, uterus, epididymis, amidst many other structures. The name "duodenum" is attributed to him. He knew that damage of the motor nerves led to paralysis. Herophilus is also given the credit for stating that pulse does not result from a mysterious power within the arteries themselves but that this power is communicated to it through the action of the heart (Von Staden 1989). The seat of consciousness, intelligence and emotions, which Aristotle ascribed to the heart, was proved to be a function of the brain by Herophilus (Peck 1965).

Science is no respecter of opinions, and is merciless towards those who jump to conclusions. Herophilus first formulated the concept of the "rete mirabile", a vascular plexus or network of blood vessels at the base of the human brain surrounding the pituitary gland. This occurs only in lower animals but not in man. Jacob Berengario da Carpi (1470-1550) later corrected the erroneous notion of the "rete mirabile" (Garrison 1969).

Erasistratus. The younger Erasistratus (310-250 B.C) was more of a physiologist. He came from the Greek island of Chios. Erasistratus is reported to have taught at the medical school that Herophilus founded (Von Staden 1992).
Cecelia Mettler in her History of Medicine reports that Herophilus and Erasistratus disliked each other very much (Mettler 1947). Although there is no corroborating evidence to reinforce her report of dislike between these two.

He formulated a "pneumatic theory" and regarded the heart as a pump. Erasistratus described the auricles of the heart, cardiac valves, blood vessels, including the aorta, pulmonary artery and veins, hepatic arteries and veins, renal vessels, superior and inferior vena cava, and the azygous vein. He also differentiated the cerebrum from the cerebellum and described the cerebral convolutions, ventricles, and meninges. Erasistratus recognized the function of the trachea. Those who ignore the interdependence of science and politics need a rethink. Alexandria began its decline with the Roman invasion lead by Julius Caesar in 47 B.C.. This was climaxed by the burning of its famous Alexandrian library. At that time the library housed most of the learning of the ancient World. Egypt subsequently became part of the Roman Empire. Under the Roman rule, the Alexandrian library and Museum library gradually fell into decay and in 391 A. D., the main library was destroyed totally by Theodosius I, who was razing all pagan temples (Durant 1939b).

Medicine was still nurtured by Greek and other scholars but was culturally in a Roman environment. Human dissection was either forbidden or not encouraged - a situation that lasted until the late Middle Ages. Like in some medical schools today, it was declared unnecessary in the training of physicians. The greatest figure of this time was the physician Claudius Galen.

Claudius Galenus (AD 131-192) was born in Pergamon in Asia Minor, a flowering centre of Hellenistic culture located near the western coast of what is now Turkey. His father, Nikon of Pergamum was a renowned architect. He was a celebrated anatomist and a leading advocate of the doctrines of Hippocrates. After Hippocrates, Galen is the most famous physician in history (Nuland 1988).

Galen's work was recorded into numerous complex treatises covering all conceivable aspects of man's knowledge. He even published a guide to his writings, entitled "On his own Books." Galen wrote more than 130 medical treatises, of which 80 have survived. These classic works became the unquestionable repository of medical knowledge for more than a thousand year after his death. As a physician to the gladiators of Pergamus he had access to many human subjects, particularly those who were injured. Many of his human anatomical descriptions were wrong because of his reliance on animal dissection. According to Galen, "The dissection of the animal will teach the seat, the number, the peculiar matter, the size, the shape, and the 
composition of every part of the body". The principal subject of his investigation was the monkey, probably the macaque because anthropomorphous monkeys were hardly available and possibly unknown in Rome at that time (Garofalo 1991). In Galen's opinion, the most suitable animals for dissection were those "with a round face", on the assumption of a close similarity of their nervous systems to that of the humans. The majority of his dissections were performed on ox brains, which he simply bought from the butcher; for in vivo dissection, pigs and goats were used to avoid the horror of the sight of a monkey being dissected alive, even though pigs and goats shout at top of their lungs. The dissection of humans played a minor role, if any, in the anatomic work of Galen.

Claudius showed that in addition to the diaphragm other muscles were involved in respiration. He left a detailed description of the origin and course of the phrenic nerve, and his discovery of the recurrent laryngeal nerve led him to comprehend voice production by the larynx. He proved that arteries as well as veins carry blood, differentiated between pia and dura mater, and described the ventricular system, pineal gland and pituitary gland. Galen described the Tela choroidea and its relation to the $3^{\text {rd }}$ ventricle. His most notable work was "Áuatomi?a? ?gceir?seiV" (Anatomical Procedures). This was initially written in the years after $\mathrm{AD} 177$, in Rome as a mature work and was partially rewritten after AD 192, because of the nearly total destruction of the original work by fire in the Temple of Peace (Garofalo).

The "rete mirabile" (a marvellous network) at the base of hoofed animal's brains was erroneously believed to be present in human brains. According to him, this was the seat of man's "animal spirit" which later became transformed into "vital spirit." He also misrepresented the shape of the human heart, branches from the aortic arch, the location of the kidneys, the shape of the liver, as well as other anatomical structures. Notable among his errors were that of just seven cranial nerves and that air enters the blood via the left ventricle (Badoe 1994).

Presumptive authoritarianism did not allow Galen's ideas to be criticized; thus many of his erroneous ideas were perpetuated and major progress in the field of anatomy was halted until the sixteenth century. It was a crime to differ from Galen. Vesalius, one of the most famous anatomists of all time was very fearful of differing with Galen (Adams 1939).

It is tempting to believe that Galen ushered a long and dark period in the history of medicine, including anatomy. However, these were era in which tradition and authority outweighed positive facts in science. Indeed,
Galen himself practised Medicine based on the four humoral paradigms of Hippocrates. After the death of Galen, the tempo of anatomical and physiological inquiry sank. This accounted for the many erroneous belief that lasted even after his death. The Galenic concepts, both accurate and inaccurate, became canonized as the theoretical basis of medicine and surgery for 15 centuries.

The Renaissance. Fresh air and light fell upon human learning again as the renaissance broke undue bounds. The Renaissance was a period during which there was a revival in the ideas of ancient Rome and Greece. Ideas flourished and the newly invented printing press allowed books to be produced quickly. Before this, books were slowly and painstakingly copied by hand. Although very few people could read and write, the printing press was a revolution in information technology and resulted in ideas spreading around Europe like never before.

Mondino de Luzzi. By the end of the thirteenth century, the demand for accurate information was so great that the medical dissection of human corpses began in earnest. The freedom from the restriction imposed by presumptive authoritarianism on human dissection had its origin in Italy. Anatomists at this time were still conditioned to revere the outdated notions of Aristotle and Galen, and if an autopsy revealed a deviation from prior teachings, the anatomists concluded that the body was abnormal.

Towards the end of the $13^{\text {th }}$ century Mondino de Luzzi a surgeon-anatomist, revived anatomical dissection in Bologna; although dissections were still often confined to the bodies of animals and sometimes they were really autopsies performed to ascertain the cause of demise especially if foul play was a possibility. These were usually the responsibility of Surgeons. Mondino also dissected the bodies of executed criminals. He produced the first manual for dissection in 1316.

The artists. The fourteenth century brought a more scientific attitude to the study of the human body. To some extent, artists, rather than scientists, set the pace in revealing new aspects on human anatomy. Leonardo da Vinci (14521519) was undoubtedly the most industrious artist, producing hundreds of anatomical drawings made from dissections

During the 200 years or so of the renaissance there was profound changes in anatomical development. The renaissance witnessed the revival of the scientific study of anatomy initially by the great artists, notably the genius Leonardo da Vinci, Johannes de Ketham and Berengario da Carpi. It was in Italy that artists such as Donatello, Michelangelo, Raphael and Leonardo da Vinci were among 
the first to take up the scientific study of human anatomy, due to their interest in human form. This was a key advancement necessary for the progression of surgery; likewise the invention of printing, making books readily available was of great help. Illustrations so necessary to anatomy could at that time be more easily reproduced and distributed.

All these artists, especially Leonardo da Vinci (1452-1519), engaged in dissection of the human body, a practice that had been non-existent since the ancient dissections of a thousand years earlier. He pictured median sagittal sections of the brain.

Berengario da Capri's "Commentaria...super anatomica mundis" and Johannes de Ketham's "Fasiculus medicinae" published in Venice (1491) are two of the most known illustrated medical works by woodcuts with pictures. The best and most lasting was that by Vesalius (1514-1564), "De humani corporis fabrica" (On the Structure of the Human Body), in which he carefully integrated text and drawings made from dissections, setting anatomy on a new course toward the scientific method. Jan Calcar, a student of Titian made the drawings. The era of growth was the era of collaboration between Arts, Technology and Science.

Although there had been sporadic anatomical demonstrations in Italian medical schools since the early 14th century, their main purpose was to help memorise the writings of a thousand years earlier. The professor sat in a raised chair and read from an inaccurate manuscript while a demonstrator pointed out the organ to the audience. When there were discrepancies between text and demonstration the professor explained that the human body had changed since Galen's time (DeBroe 1997). Authoritarianism and good science do not often go together.

Five years before the death of Leonardo, the true "Father of Anatomy" was born. This was Andreas Vesalius.

Andreas Vesalius was born in Brussels on December 31, 1514 into a family of physicians (Simeone 1984). His ancestors were intellectuals, well versed in the natural sciences, music, ancient languages and philosophy. For at least four generations they serve in the imperial medical services (O'Malley 1954). Vesalius was educated in Brussels and Paris and he went to Padua to finish his medical study. He broke the then established rigid and fabricated way of teaching anatomy and introduced the modern concept of learning based on observations using illustrations combined with a critical spirit and sense of experiment (Jackson 1992). He was a surgeon-anatomist and the founder of modern anatomy,
The illustrations of Vesalius' dissections were rendered with remarkable clarity by an extraordinary artist, Jan Stephan Kalkar, and were reproduced both as woodcuts and copper plates. A transformation occurred in the precise anatomy of humans with the publication in August 1543 of "De humani corporis fabrica" (the 7th and last of his fabrica) by Vesalius who was then just 28years of age (O'Malley). This folio-sized book is the foundation of modern topographic human anatomy and one of the most important books in the history of medicine. It included plates of osteology and myology series. Vesalius spoke of the "Divinus opifex" i.e. the Divine designer and constructor of the universe and of man or of the "Divinus artifex", the divine artisan who organized minute details and fastened together the various parts.

Vesalius' description of the cerebral vessels is generally adequate but he overlooked the hexagonal ring of communicating arteries at the base of the brain. Like da Carpi, he disputed Galen on existence of the rete mirabile, stating that it is almost non-existent in humans. Authority has a fragile confidence, because it rightly suspects though it could be wrong. The demonstrations of the many errors in the anatomic publications of Galen were initially met with mixed reactions. Especially vehement was the reaction from his former teacher of Vesalius few years earlier, Jacob Sylvius who called his work filth and sewage 17. Impulsively and not entirely rational, Vesalius burned all his manuscripts. This ended his 5years of academic work; the next 20 years were to be boring and barren. Sylvius was wrong while Vesalius was right; but the right course was under erroneous authority and progress suffered.

There is such a thing as an atmosphere conducive to intellectual growth and burst. The "De humani corporis fabrica" coincided with the publication of another great book in the history of science the "De revolutionibus orbium coelestium" of Nicolaus Copernicus. Thus in a single year, the modern understanding of both the microcosm and macrocosm was set under way, and man's place in the world took a new dimension. The "De humani corporis fabrica" is one of the greatest medical books ever written because it introduced and established a new mode of thought for anatomy as a medical science. Its significance lay in the fact that for the first time anatomy became based on objective observation, accurate recording and presentation of data and pursuit of concepts to logical conclusions19. From his careful observations he challenged the many centuries old dogma of Galen and transformed anatomy to a highly developed science and the foundation of modern medicine, leaving durable imprints with respect to the development of anatomy. 
MALOMO, A. O.; IDOWU, O. E. \& OSUAGWU, F. C. Lecciones de historia: Anatomía Humana desde el origen hasta el Renacimiento. Int. J. Morphol., 24(1):99-104, 2006.

RESUMEN: El hecho bien conocido que los historiadores siempre parecen ser más sensatos que los sujetos sobre quienes escriben, es la más lógica prueba que la historia es rica en lecciones. La historia de la Anatomía no es la excepción. Ella está llena de lecciones imperativas en el arte y ciencia, de la cual generaciones venideras deberían aprender. Presentamos un breve reconocimiento sobre lecciones de la Historia de la Anatomía.

PALABRAS CLAVE: Hipócrates; Galeno; Herófilo; Vesalio.

\section{REFERENCES}

Adams, F. The complete Works of Hippocrates. Adams, F. ed. Baltimore, Williams \& Williams, 1939. pp. 1-10.

Anson, B. J. Moris Human Anatomy-A complete systematic treatise. London, Mcgraw Hill, 1-20, 1908.

Badoe, E. A. Brief history of surgery. In: Badoe, E. A.; Archampong, E. Q. \& Jja, M. O. A. Principles and practice of surgery including pathology in the tropics. $1^{\text {st }}$ ed. Tema, Ghana publishing corporation, 1994. pp111 .

DeBroe, M. E.; Sacre, D.; Snelders, E. D. \& Weerdt, D. E. The Hemish Anatomist Andrea Vesalius (1514-1564) and the Kidney. Am. J. Nephrology, 17(3-4):252-60, 1997.

Durant, W. Aristotle, History of Animals. In: Durant W, ed. The Story of Civilization. New York, Simon and Schuster, 1939a. pp 410-671.

Durant, W. The life of Greece. The story of Civilization. New York: Simon and Schuster, 1939b. V. 2. pp. 337400 .

Edelstein, L. The History of Anatomy in Antiquity. Temkin O.; Temkin, C. L. eds. Ancient Medicine. Baltimore, Johns Hopkins Press. 1-23, 1967.

Garofalo, I. G. Procedimenti anatomici. Milano, Rizzoli. 1991. p 854.

Garrison, F. H. History of Neurology. Revised and enlarged by McHenry L. C.; Charles C. Thomas \& Springfield, I. L. 1969. pp. 4-9.

Gillespie, C. Praxagoras. The Dictionary of Scientific Biography. New York, Scribner, 1980, pp. 316-9.

Gordon, G. L. Medicine Throughout Antiquity. Philadelphia, FA Davis Publishers. 589-608, 1949.
Jackson, B. T. An introduction to the history of Surgery. In: The new Aird's companion in surgical studies. Churchill Livingstone, 1992. pp. 1-26

Mettler, C. Medicine in Alexandria. In: Mettler F, e. History of Medicine. Philadelphia, The Blakiston, 1947. pp. 331-3.

Nuland, S. The Bibliography of Medicine. $2^{\text {nd }}$ ed. New York, Vintage Books, 1988. pp. 61-93.

O’Malley, C. D. Andreas Vesalius, count palatine. Further information on Vesalius and his ancestors. J. Hist. Med. Allied Sci., 9:196-223, 1954.

Peck, A. L. Historia Animalium by Aristotle. Cambridge, MA, Havard University Press, 1965, pp. 1-6.

Phillips, E. D. Greek medicine. London, Thames and Hudson. 4-33, 1973.

Simeone, F. A. Andreas Vesalius: Anatomist, Surgeon, Count palatine and Pilgrim. Am. J. Surgery, 147:432, 1984.

Von Staden, H. Herophilus: The art of Medicine in Alexandria. $1^{\text {st }}$ ed. Cambridge, MA: Cambridge University Press. 1-666, 1989.

Von Staden, H. The discovery of the body. Human dissection and its cultural contexts in Ancient Greece. The Yale J. of Biology and Medicine, 65:223-41, 1992.

Correspondence to:

Dr. O. E. Idowu

Division of Neurological Surgery

Department of Surgery,

University College Hospital

Ibadan

NIGERIA

E-mail-oeidowu412@yahoo

Received: 31-08-2005 Accepted: 04:01-2006 